\title{
CITIZEN JOURNALISM MELAWAN MAINSTREAM MEDIA
}

\author{
Senja Yustitia \\ (senja_06@yahoo.com) \\ Dosen Jurusan Ilmu Komunikasi Universitas Semarang
}

\begin{abstract}
The importance of mass media tend to described as the fourth pillar of a nation, that represents democration, after the existence of nation sets of government forces. In line with teori agenda setting thesis emphasize media force to influence society agenda, and in the end will brought particular change towards. Post-reformation, media tend to isolate themselves from society needs although society is their biggest and the most loyal audiences. Thus called mainstream media consider economic importance as the most important aspect, this fact encouraging media to deviate from their main purpose as the provider of idea and knowledge, whether to give out information or to accomodate various needs and interest. This condition known as "the end of media", related with this condition the emergence an alternate known as citizen journalism really needed to balance out information current. The existence of citizen journalism encourage audience to participate as subject and object to control journalistic mechanism.
\end{abstract}

Keywords : mainstream media, agenda setting, citizen journalism.

\section{Pendahuluan}

Menteri Kesehatan Siti Fadilah Supari menuliskan beberapa keluhannya terkait dengan kinerja media dalam bukunya "Saatnya Dunia Berubah". Dari 202 halaman buku tersebut, beberapa kali ia menyinggung pemberitaan media dan kecakapan wartawan dalam mengulas virus flu burung. Diakuinya, opini yang dihembuskan media sedikit banyak membuat penanganan wabah ini terhambat. Bahkan, Menkes justru memuji kinerja jurnalis asing yang jeli melihat esensi dari permasalahan sehingga isu yang berkembang membantunya berjuang di level internasional terkait dengan sharing virus H5N1.

Kekecewaan Menkes bisa jadi karena ia adalah pihak yang dirugikan dalam pemberitaan pers Indonesia. Tapi di sisi lain, inilah wajah media massa
Indonesia. Pers kini tidak lagi fokus pada fungsi-fungsi dasar media massa. Dalam lingkup yang lebih luas, pers Indonesia gagal menjalankan fungsinya untuk menyuarakan kepentingan pihakpihak yang lemah dalam hal ini Indonesia yang berhadapan dengan negara maju, khususnya Amerika Serikat. Wabah flu burung hanya dilihat dari aspek ketidakbecusan pemerintah dalam melindungi rakyatnya serta ketidakmampuan dalam memberikan pelayanan kesehatan. Media cukup jarang meng-cover wabah ini dari tataran yang lebih luas. Sudut pemberitaan yang cenderung kontra dengan pemerintah dilihat sebagai sebuah isu yang laku (saleable) dan pantas diberitakan karena mendongkrak penjualan. Di lain sisi, sikap pro pemerintah tidak lagi populer di hadapan pembaca maupun kompetitor.

Pernyataan Menkes bukanlah 
satu-satunya kritik terhadap kinerja media massa setelah dibukanya kran kebebasan pers. Pengurus Partai Demokrat Ahmad Mubarok dalam sebuah berita mengatakan bahwa perseteruan Partai Golkar dan partainya pada masa pemilu 2009 dikarenakan efek pemberitaan media massa. Statemen bahwa perolehan suara Partai Golkar bisa jadi berada di bawah Partai Demokrat tidak dikutip dengan sempurna sehingga menimbulkan persepsi yang berbeda. Pers kerap kali dituding tidak bisa menempatkan diri dalam peristiwa konflik atau peperangan. Sehingga munculah dikotomi jurnalisme perang dan jurnalisme damai. Jurnalisme perang digunakan untuk menyebutkan kinerja media yang justru memicu konflik makin tajam dengan berbagai cara. Salah satunya adalah dengan pemberitaan yang berat sebelah dengan angle liputan tertentu. Sedangkan jurnalisme damai berusaha meminimalkan celah antara pihak yang berlawanan dengan tidak mengulangi "fakta" yang memperparah atau meningkatkan konflik (Syahputra, 2006:89-90). Nafas dari jurnalisme damai adalah agar peperangan tidak semakin luas dan memakan korban lebih banyak lagi.

Kenyataan ini membuat kondisi pers Indonesia berada di persimpangan jalan jika tidak ingin disebut sedang berjalan mendekati sebuah proses "kematian media". Kematian media adalah istilah yang dikenalkan Danny Shecther untuk menunjukkan kondisi dimana media tidak lagi bisa menjalankan fungsinya.

Pentingnya peran media massa kerap diibaratkan sebagai tiang ke-4 demokrasi sebuah negara setelah keberadaan lembaga yudikatif, legislatif dan eksekutif. Dalam prinsip ini, media menjadi sebuah kekuatan yang sangat penting dalam kehidupan bernegara. Sinkron dengan tesis teori agenda setting yang menekankan bahwa kekuatan media bisa mempengaruhi agenda masyarakat yang pada akhirnya diharapakan merubah agenda publik. Signifikannya peran media tanpa disadari juga sangat berpengaruh pada kinerja awak media. Baik negatif maupun positif.

Positif, jika kinerjanya diimbangi dengan profesionalitas. Profesionalitas pribadi sebagai pekerja media, akan mempengaruhi cara kerja insititusi, dalam hal ini perusahaan media tersebut, sehingga tercermin dalam produk media yang dinikmati oleh khalayak luas. Namun, bisa berubah menjadi energi negatif jika signifikansi media ditanggapi dengan sikap jumawa dan masa bodoh oleh pekerja media. Media tidak lagi menjadi sarana untuk membantu masyarakat agar tahu dan peduli dengan lingkungan serta sebagai sumber informasi terkini. Sebaliknya justru membangun realitas semu yang berdasarkan prinsip-prinsip ekonomi. Media tidak lagi takut membuat kesalahan melalui liputanliputan dengan tingkat akurasi yang rendah. Posisi media yang seakan-akan tidak tersentuh ini justru membuat media menjadi kebal kritik sekaligus kebal hukum. Pekerja media lantas berdiri di balik kebebasan pers untuk membela kepentingan-kepentingan institusinya.

\section{Perkembangan Pers Indonesia dari Masa ke Masa}

Perkembangan kehidupan pers di Indonesia mempunyai sejarah yang panjang. Pers, khususnya media cetak selalu mengalami perubahan mengikuti kondisi negara. Sebelum abad 20 dimana Indonesia masih di bawah penjajahan Belanda, secara garis besar pers dibagi ke dalam 3 golongan. Yang 
pertama adalah pers milik Belanda yang digunakan pemerintah kolonial untuk menyuarakan kepentingannya atas rakyat Indonesia. Koran-koran pembawa suara pemerintah Belanda ini misalnya Javache Courant (Surjomihardjo, 2002:26-27). Walaupun ada beberapa koran yang kontra dengan pemerintah Belanda, namun kala itu skalanya masih kecil dan bisa dikendalikan oleh pemerintah setempat. Seiring dengan makin majunya teknologi pertanian dan ekonomi, lahirlah koran-koran yang bercorak teknik. Dari ikhtisar perkembangan pers tersebut, pada mulanya pers terbit sebagai bagian usaha orang Belanda dan kemudian menjadi pembawa kepentingan perusahaan perkebunan dan industri minyak (Surjomihardjo, 2002:26-27). Di akhir abad 19 ini sebenarnya sudah muncul gerakangerakan yang menuntut kebebasan pers. Protes tersebut justru berasal dari wartawan-wartawan berkebangsaan Belanda sendiri (Surjomihardjo, 2002:27).

Gelombang protes ini berlanjut hingga awal abad 20. Bedanya, jika pada awalnya tuntutan kebebasan pers disuarakan oleh para jurnalis Belanda, kini kaum pribumi pun menyuarakan hal yang serupa. Pers pada awal abad 20, dapat dibedakan menjadi 2 kelompok besar yakni pers nasional dan pers kolonial. Pers nasional merujuk pada pers yang digunakan sebagai alat perjuangan kemerdekaan Indonesia dari penjajahan termasuk menampung pemikiran-pemikiran kritis berbagai pihak, khususnya kalangan muda. Sedangkan pers kolonial digunakan untuk menyebut koran yang digunakan pemerintah Belanda dan Jepang. Misalnya koran Java Bode yang selalu membela Belanda termasuk mendapatkan hak istimewa berupa pasokan berita dari pemerintah. Tidak berbeda dengan Belanda, Jepang pun menggunakan pers untuk membela kepentingannya di Indonesia. Koran diawasi dan berada di bawah kontrol pemerintah Jepang. Seperti, Jawa Shinbun, Sumatera Shinbun, Borneo Shinbun dan lain-lain (Smith, 1983:84). Memasuki pemerintahan Orde Lama, ide tentang kebebasan pers kembali menguat. Terbukti pada Agustus 1953 di Denpasar, PWI meminta pemerintah mengeluarkan undang-undang pers baru, setelah Persbreidel Ordonantie milik Belanda dicabut oleh pemerintah. Pada masa ini, juga terlihat sekali betapa kehidupan pers sangat dipengaruhi oleh sistem negara. Kebebasan pers bertambah besar ketika sistem politik beralih ke bentuk demokrasi liberal antara tahun 1955-1959. Pada masa ini hampir setiap surat kabar memiliki hubungan tertentu dengan satu partai politik (Hamad, 2004:62). Sedangkan saat masa demokrarsi terpimpin, pers dijadikan instrumen pemerintah otoriter.

Orde Baru adalah masa dimana pers Indonesia mengalami tekanan yang amat besar. Pada awalnya UU Pokok Pers No 11/66 jo UU No. 4/1967 tidak mengatur Surat Ijin Terbit (SIT) dan brendel. Namun, pers yang digunakan untuk mendukung pemerintah membuat aturan ini dilanggar. Campur tangan pemerintah makin besar saat diterbitkan UU Pokok Pers No. 21/1982 yang mewajibkan semua penerbitan media massa mengajukan Surat Ijin Usaha Penerbitan Pers (SIUPP). Hal ini membawa konsekuensi, bahwa sewaktu-sewaktu pemerintah bisa mencabut SIUPP jika media tersebut dinilai melenceng dari kebijakan pemerintah.

Orde Reformasi adalah pintu bagi kebebasan pers yang sudah dicitacitakan sejak awal abad 20. UU No 40/1999 tentang pers mengatur bahwa 
pembentukan media tidak perlu melalui mengajuan SIUPP terlebih dahulu. Jika ditelaah sepintas, maka UU ini selain menjadi salah satu tonggak demokrasi, juga merupakan impian dari kalangan pers yang sejak lama dibungkam. Dampak pertama yang langsung terlihat adalah menjamurnya media massa baik elektronik maupun cetak. Kendati kemudian jumlah media berangsurangsur turun beberapa tahun kemudian namun jumlahnya tetap meningkat jika dibandingkan pada masa Orde Baru.

Adanya UU tersebut membuat kehidupan pers berubah total. Dari awalnya digunakan sebagai instrumen pemerintah sehingga pemberitaannya selau pro penguasa kini tidak lagi. Pers tidak lagi takut untuk berseberangan dengan pemerintah, pendapat dan analisa dari tokoh-tokoh kritis juga tercover dengan baik tanpa takut dibrendel.

\section{Tren Media Saat Ini}

Dari segi bisnis media, banyaknya media baru membuat "kue" iklan yang selama ini dinikmati oleh beberapa pemain kini tersebar ke berbagai media baru dan lama. Kompetisi menjadi ketat sehingga bagi yang tidak siap dengan persaingan ini mereka akan mati. Di satu sisi, kondisi ini mengundang para pemodal yang sebelumnya tidak bermain di bisnis media. Banyaknya media-media baru membuat tingkat kompetisi makin tinggi sehingga kekuatan modal menjadi salah satu faktor yang penting. Kondisi tersebut disikapi dengan menghilangkan kompetisi itu sendiri dengan cara melakukan konglomerasi media secara besar-besaran. Misalnya seperti yang dilakukan kelompok MNC dengan menguasai 3 stasiun televisi sekaligus yakni RCTI, Global TV dan TPI serta koran Seputar Indonesia.

Keluarga Sariatmaja yang kini menguasai SCTV, dikabarkan rencananya juga akan menggandeng Indosiar yang tengah kolaps. Di sektor televisi lokal, mereka mendirikan OChannel dan juga beroperasi di sedikitnya 2 radio ibu kota, yakni Cosmopolitan dan Hard Rock FM. Surya Persindo yang dimiliki oleh Surya Paloh mengawali bisnis media di sektor cetak dengan Media Indonesia yang merupakan produk unggulan grup ini. Selain itu, ia juga turut menanamkan modal di sedikitnya 10 koran dan majalah lokal yang tersebar di Indonesia seperti Peristiwa, Aceh Post, Mimbar Umum, Semangat dan lain-lain. Di sektor elektronik, mereka membuat Metro TV, produk yang diklaim sebagai televisi berita.

ANTV 20 persen sahamnya dikuasai grup Bakrie. Grup Bakrie sendiri berkongsi dengan grup Mahaka milik Eric Thohir untuk mengelola televisi baru, TVOne. Eric juga bermain di televisi lokal dengan Jak TV dan media nasional Republika. TransTV milik Chaerul Tanjung merger dengan TV 7 (Trans 7) yang merupakan salah satu induk usaha KKG (Kelompok Kompas Gramedia Group) milik Jakob Oetama yang tak lain adalah bos harian Kompas. Kompas sendiri hingga kini membawahi sedikitnya 23 media cetak baik yang berbentuk, harian, mingguan, bulanan dan dwi bulanan.

$$
\text { Jawa Pos Group setidaknya }
$$
hingga kini mempunyai induk penerbitan di lebih dari 50 media cetak seluruh Indonesia. Belakangan mereka juga membuat JTV (Surabaya), Batam TV (Batam), Riau TV (Pekanbaru) dan sedang membangun Malioboro TV di Jogjakarta. Di jajaran TV lokal, ada kelompok Bali TV yang kini membawahi 7 stasiun televisi lokal di 7 daerah, baik yang sedang proses berdiri maupun yang sudah berkibar. Sebut saja, Bandung TV (Bandung), Jogja TV 
(Jogjakarta), Cakra TV (Semarang), Surabaya TV (Surabaya), Aceh TV (NAD), Balikpapan TV (Balikpapan), Makasar TV (Makasar TV).

Merger yang dilakukan MNC membuat mereka makin kuat. Menurut data Nielsen, pada kuartal pertama 2006 saja total pendapatan iklan yang diraup tiga stasiun televisi kelompok MNC mencapai 32 persen dari nilai total pendapatan iklan di media televisi yang saat itu mencapai $\mathrm{Rp}$ 13,6 triliun. Pemilik Kompas Gramedia serta TV 7 Jacob Oetama dan Direktur Trans TV Ishadi dalam wawancaranya dengan majalah Cakram edisi Desember 2006 memandang kondisi media saat ini memaksa mereka untuk merger karena tidak mungkin stand alone. Di lain sisi, media kecil yang tidak punya kekuatan modal seperti mereka lebih memilih menjadi corong pemerintah untuk mendapatkan keuntungan atau minimal eksistensinya bisa terjaga. Kecenderungan ini kerap terjadi oleh media-media lokal yang lebih dekat dengan pusaran kekuasaan pemerintah di daerah.

Teori ekonomi politik media yang masuk dalam lima genre utama teori media kritis dapat menjelaskan fenomena ini dengan komprehensif. Menurut Vincent Moscow pendekatan teori ekonomi-politik media pada intinya berpijak pada pengertian ekonomi politik sebagai studi mengenai relasi sosial, khususnya yang menyangkut relasi kekuasaan, baik dalam produksi, distibusi dan konsumsi sumber daya (resourches) (Junaedi, 2007:34). Teori ini menganggap bahwa kepemilikan media pada segelintir elit pengusaha telah menyebabkan patologi atau penyakit sosial. Kandungan media adalah komoditas yang dijual di pasar, dan informasi yang disebarluaskan dikendalikan oleh apa yang pasar akan tanggung. Sistem ini membawa implikasi mekanisme pasar yang tidak ambil resiko, suatu bentuk mekanisme pasar yang kejam karena membuat media tertentu mendominasi wacana publik dan lainnya terpinggirkan (Junaedi, 2007:34).

Kenyataan ini membawa konsekuensi bahwa khalayak tidak lagi mempunyai pilihan untuk mendapatkan informasi yang beragam karena media hanya dikuasai segelintir orang. Menutup kompetisi dengan meniadakan kompetisi ini sebenarnya membuat media justru lebih mudah dikendalikan oleh pemodal dan penguasa atau dalam hal ini pemerintah. Tentu saja ini justru melenceng dari nafas kemerdekaan pers yang digaungkan sejak awal reformasi. Hitung-hitungan bisnis menjadi tujuan utama dalam operasi media. Di lain sisi, media menjadi sangat jauh dengan publik. Apa yang ditampilkan media untuk memanjakan para pemodal dan menjadi sebuah bingkai yang kerap membentuk dunia sendiri. Media tidak lagi memberikan tempat kepada publik untuk memberikan feedback dan kritik.

Menurut Schechter ada beberapa ciri yang ditunjukkan oleh media menjelang pada kondisi matinya media yang terjadi di Amerika beberapa tahun belakangan. Media yang dimaksudkan untuk menggiring demokrasi sebuah negara justru gagal menjalankan perannya (Schechter, 2007:2). Melalui cara-cara tertentu mereka menukar demokrasi dengan "mediaokrasi"-yang diatur lewat kekuatan penentuan agenda setting korporasi media milik segelintir pemain swasta. Pekerja media, khususnya jurnalis, paham betul bagaimana tekanan korporasi begitu menggoda. Akibatnya diri pribadi mereka pun kian terjajah. Banyak yang berdalih bahwa mereka tak punya banyak cara untuk melawan. Dan yang jelas terjadi adalah bahwa hubungan antar perusahaan-perusahaan besar 
justru tidak bersifat antagonis. Satu dengan yang lainnya berbisnis sampai miliaran dollar. Mereka tidak saling bersaing. Mereka justru bekerja sama untuk menghindari kompetisi (Schechter, 2007:3-4)

$$
\text { Media massa Indonesia }
$$

kredibilitasnya makin diragukan banyak pihak. Tidak sedikit khalayak yang melihat bahwa media kini tidak lagi menyiarkan informasi yang benar. Kompetisi yang seharusnya membuat masing-masing media meningkatkan performanya justru disikapi dengan menutup kompetisi itu sendiri dengan konglomerasi media. Salah satu solusi yang cukup masuk akal adalah dengan membuka kembali kompetisi yang telah hilang. Caranya dengan memunculkan media yang bisa dijadikan alternatif, agar khalayak mempunyai pilihan dan terlibat langsung dalam sebuah mekanisme jurnalistik.

\section{Solusi: Citizen Journalism}

Citizen Journalism (CJ) yang juga dikenal dengan beragam nama lain, seperti participatory journalism atau grassroot journalism adalah jurnalisme orang biasa. Sesorang tanpa memandang latar belakang pendidikan dan keahlian, dapat merencanakan, menggali, mengolah, dan merepresentasikan informasi, berupa tulisan, gambar, foto, tuturan (laporan lisan), video dan lain-lain dalam citizen journalism (Yudhapramesti, 2007:35). CJ hadir untuk menutupi kebutuhan khalayak terhadap beragam informasi yang tidak bisa disuguhkan oleh media massa umumnya atau yang disebut dengan mainstream media. Kredibilitas mainstream media yang makin diragukan, membuat CJ menjadi pilihan khalayak untuk mendapatkan keragaman informasi. Di Amerika dan Korea Selatan, CJ sudah berangsurangsur menggantikan peran mainstream media. Blog Ohmynews milik Oh Yeon-ho memiliki lebih dari 42 ribu kontributor berita, mempunyai 42 ribu versi berita. Situs ini juga diakses 700 ribu orang setiap harinya (Haryati, 2007:vi). Wikimu.com (www.wikumu.com) juga menerapkan mekanisme yang sama. Setiap orang bisa mengirimkan beritanya. Pengunjung yang lain juga berhak untuk memberikan sanggahan atau bahkan menambahi setiap berita. Kompas.com (www.kompas.com) kini juga mencoba memberikan tempat bagi warga biasa untuk mengirimkan beritanya melalui link "koki" yang diklaim sebagai citizen journalism dengan motto "siapa saja menulis apa saja".

Dalam skala yang lebih kecil, CJ bisa berbentuk blog yang bisa dimiliki secara gratis oleh setiap orang. Pemilik blog bisa menceritakan apapun yang diketahuinya. Tulisannya bisa dikomentari oleh setiap pengunjung, baik komentar yang pro atau kontra. Isi blog hanya dikendalikan oleh pemilik blog sehingga tidak ada proses gatekeeping seperti yang selama ini ada di mainstream media.

Di Indonesia, CJ mulai marak setelah adanya pesta blogger 2007 lalu di Jakarta. Sebuah event yang mempertemukan para blogger dari seluruh Indonesia ini meneguhkan akan kebutuhan khalayak terhadap informasi yang tidak dimanipulasi oleh korporat dan semangat bahwa setiap orang mampu mempunyai media sendiri. Setelah ajang ini, ribuan blog lahir setiap hari. Blog-blog yang ada di dunia maya bahkan kini tidak hanya berbentuk buku harian elektronik namun lebih dari itu. Banyak diantara pemilik blog tersebut adalah para profesional, pendidik, dan bahkan beberapa tokoh politik Indonesia yang merasa lebih bebas berbicara melalui blog daripada media massa yang sangat 
rentan dengan pengolahan berita. Beberapa blog milik tokoh terkenal dan pakar adalah blog dongeng geologi (www.rovicky.wordpress.com) yang dibuat oleh Rovicky. Blog ini berisi tentang informasi-informasi tentang fenomena alam seperti gempa bumi dan lain-lain yang kadang disikapi dengan salah kaprah oleh masyarakat luas. Blog www.pralangga.org yang menceritakan misi perdamaian PBB di Afrika. Blog lain yang juga menjadi rujukan para pengunjung yang berminat dalam bidang politik adalah www.intelindonesia.blogspot.com.

Beberapa tokoh politik juga membuka ruang diskusi di blog seperti Yusril Ihza Mahendra (www.yusrilihzamahendra.com), Anwar Ibrahim (www.anwaribrahimblog.com), Wimar Witoelar (www.wimarperspektif.net). Intinya CJ mampu mengisi kekosongan yang tidak bisa dipenuhi oleh mainstream media terkait dengan keragaman informasi dan tekanan pemodal serta pengiklan terhadap isi media.

Secara garis besar CJ memiliki beberapa kelebihan. Pertama, adanya feedback langsung dari pembaca sehingga terjadi dialog antar penulis dengan pembaca serta pembaca dengan pembaca lainnya. Hal ini membuat khalayak mempunyai banyak pilihan informasi dan sarana debat. Kedua, melibatkan khalayak luas sebagai kontributor berita. Baik itu yang berbentuk situs berita yang dikelola beberapa orang maupun blog yang dimiliki perseorangan. Sehingga suarasuara orang yang selama ini tidak dapat ditampung di mainstream media bisa disampaikan kepada khalayak luas. Ketiga, CJ tidak dikendalikan oleh korporat, sehingga setiap orang bebas memberikan input. Para kontributor juga tidak dibayar, tidak ada biaya iklan sehingga tekanan terhadap $\mathbf{C J}$ nyaris tidak ada. Keempat, CJ relatif lebih cepat dan tidak terbatas. Hanya dengan mem-posting berita atau meng-upload video dan foto beberapa detik, informasi tersebut sudah bisa diakses khalayak luas. Sehingga kejadiankejadian penting bisa lebih cepat sampai ke pembaca. CJ juga tidak terbatas pada durasi dan space halaman sehingga pembaca bisa menikmati informasi dengan utuh. Keenam, CJ tidak melalui mekanisme gatekeeping sehingga pengolahan berita yang terjadi di news room dapat diminimalisasi.

Kendati memiliki banyak kelebihan, bukan berarti CJ tidak mempunyai kelemahan. Pertama, jika dihubungkan dengan akses internet yang masih sangat rendah di Indonesia, maka CJ masih membutuhkan waktu agar bisa lebih eksis dan diakses oleh banyak orang. Kedua, karena ditulis oleh orang yang mungkin tidak mendapatkan pendidikan jurnalistik maka akurasi berita dikhawatirkan rendah. Ketiga, penulis-penulis CJ kerap kali tidak mencantumkan identitas yang yang lengkap atau bersifat anonim. Namun di lain sisi, sifat anonim inilah yang justru membuat CJ eksis. Pasalnya, dengan menanggalkan identitas maka penulis bisa bebas menuliskan apa saja tanpa takut adanya sensor dan tekanan dari pihak tertentu.

Meminjam istilah Dennis McQuail yakni media dalam konteks mediasi, ada 7 penanda yang bisa diperankan oleh CJ. Pertama, media adalah jendela yang memungkinkan kita untuk melihat fenomena yang terjadi melebihi lingkungan dekat kita. Kedua, media merupakan penerjemah yang membantu kita membuat perasaan mengalami. Ketiga, media menjadi platform atau pembawa yang menyalurkan informasi, komunikasi interaktif (yang meliputi umpan balik 
kepada khalayak). Keempat, media adalah penanda yang memberi kita dengan instruksi dan petunjuk. Kelima, media merupakan penyaring yang menyaring bagian-bagian pengalaman dan berfokus pada lainnya. Keenam, media adalah cermin yang memantulkan realitas kita kepada kita kembali, dan terakhir, media merupakan pembatas yang menghalangi kebenaran (Junaedi, 2007:16-17).

\section{Penutup}

Kelemahan dari CJ sebenarnya bisa dimimalisasi dengan menggiatkan proses komunikasi antar pribadi (interpersonal communication). Komunikasi antar pribadi adalah komunikasi antara orang-orang secara tatap muka, yang memungkinkan setiap pesertanya menangkap reaksi orang lain secara langsung, baik secara verbal ataupun non-verbal (Mulyana, 2000:73). Dalam kaitannya dengan citizen journalism, masing-masing individu yang mempunyai keterjangkauan dengan internet bisa meneruskan informasi kepada individu lain.

Dengan komunikasi yang intens dua arah maka individu tersebut mempunyai pilihan-pilihan informasi yang membantunya dalam memutuskan sesuatu. Peran opinion leader dalam hal ini cukup penting, agar dominasi informasi tidak hanya dipegang oleh mainstream media karena dengan citizen journalism, khalayak makin berdaya dan ikut terlibat dalam alur arus informasi.

Saat citizen journalism makin eksis, maka diharapkan mainstream media berangsur-angsur memperbaiki diri karena dipaksa berkompetisi. Mereka harus memperbaiki konten media dan manata manajemen lebih profesional. Media massa dikembalikan kepada rel sebagai pelayan publik bukan pelayan pengiklan. Manajemen media juga menentukan bagaimana kinerja dan tampilan mereka. Media yang ditata dengan manajemen yang baik, membuat wartawan bekerja dengan profesional. Koran-koran lokal yang dibawah manajemen koran nasional, bukanlah alat pengeruk uang di daerah. Harus diakui bahwa koran daerah yang datang belakangan setelah pemimpin pasar, selalu perlu waktu untuk membentuk pasar sendiri. Dengan strategi segmentasi yang tepat dan backup dari induk perusahaannya, bukan mustahil mereka akan kuat sehingga mempunyai bargaining posisition yang setara dengan para penguasa daerah.

\section{Daftar Pustaka}

Hamad, Ibnu. 2004. Konstruksi Realitas Politik dalam Media Massa, Sebuah Studi Critical Discourse Analysis terhadap Berita-Berita Politik. Jakarta. Granit.

Haryati. 2007. Selamat Datang Jurnalisme Warga. Kajian Komunikasi dan Informatik Volume 5.

Junaedi, Fajar. 2007. Komunikasi Massa Pengantar Teoritis. Jogjakarta. Santusta.

Yudhapramesti, Pandan. 2007. Citizen Journalism (CJ) sebagai Media Pemberdayaan Warga. Kajian Komunikasi dan Informatika Volume 5.

Schechter, Danny. 2007. Matinya Media, Perjuangan Menyelamatkan Demokrasi, Jakarta. Yayasan Obor Indonesia. 
Smith, Edward C. 1983. Sejarah Pembredelan Pers di Indonesia. Jakarta. Grafiti Pers.

Surjomihardjo, Abdurahman. 2002. Beberapa Segi Perkembangan Sejarah Pers di Indonesia. Jakarta. Penerbit buku Kompas.
Syahputra, Iswandi. 2006. Jurnalisme Damai Meretas Ideologi Peliputan di Area Konflik, Memahami Konflik sebagai Realitas Sosial yang Terbentuk, Posisi Media dalam Peliputan Konflik, Konflik Sosial dan Dilema Wartawan, Beberapa Contoh Kisah Peliputan di Area Konflik. Jogjakarta. P_IDEA. 